\title{
Clinical applicability of optogenetic gene regulation
}

\author{
Nina Wichert ${ }^{1}$, Martin Witt ${ }^{1}$, Thomas Scheper ${ }^{2}$, and Cornelia Blume ${ }^{1}$ \\ ${ }^{1}$ Leibniz University Hannover Faculty of Natural Sciences \\ ${ }^{2}$ University of Hannover
}

November 25, 2020

\begin{abstract}
The field of optogenetics is rapidly growing in relevance and number of developed tools. Amongst other things, the optogenetic repertoire includes light-responsive ion channels and methods for gene regulation. This review will be confined to the optogenetic control of gene expression in mammalian cells as suitable models for clinical applications. Here optogenetic gene regulation might offer an excellent method for spatially and timely regulated gene and protein expression in cell therapeutic approaches. Well-known systems for gene regulation, such as the LOV-, CRY2/CIB-, PhyB/PIF-systems, as well as other, in mammalian cells not yet fully established systems will be described. Advantages and disadvantages with regard to clinical applications are outlined in detail. Among the many unanswered questions concerning the application of optogenetics, we discuss items such as the use of exogenous chromophores and their effects on the biology of the cells and methods for a gentle, but effective gene transfection method for optogenetic tools for in vivo applications.
\end{abstract}

\section{Hosted file}

24-11-20-Review.pdf available at https://authorea.com/users/378725/articles/495128-clinicalapplicability-of-optogenetic-gene-regulation

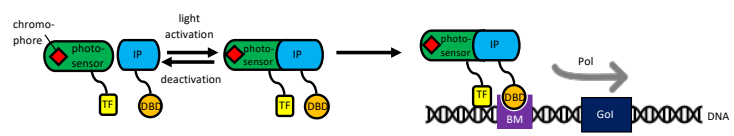



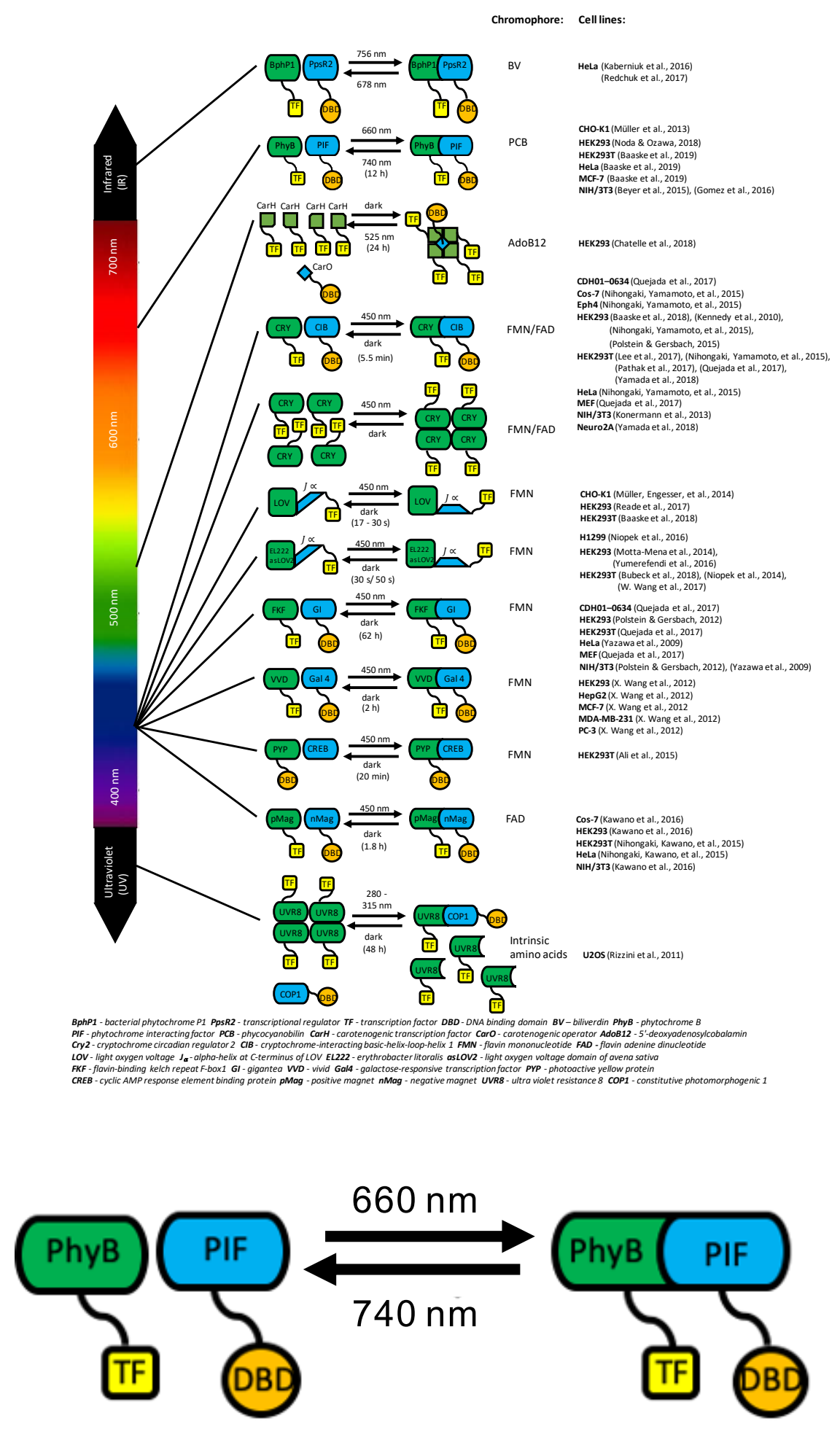

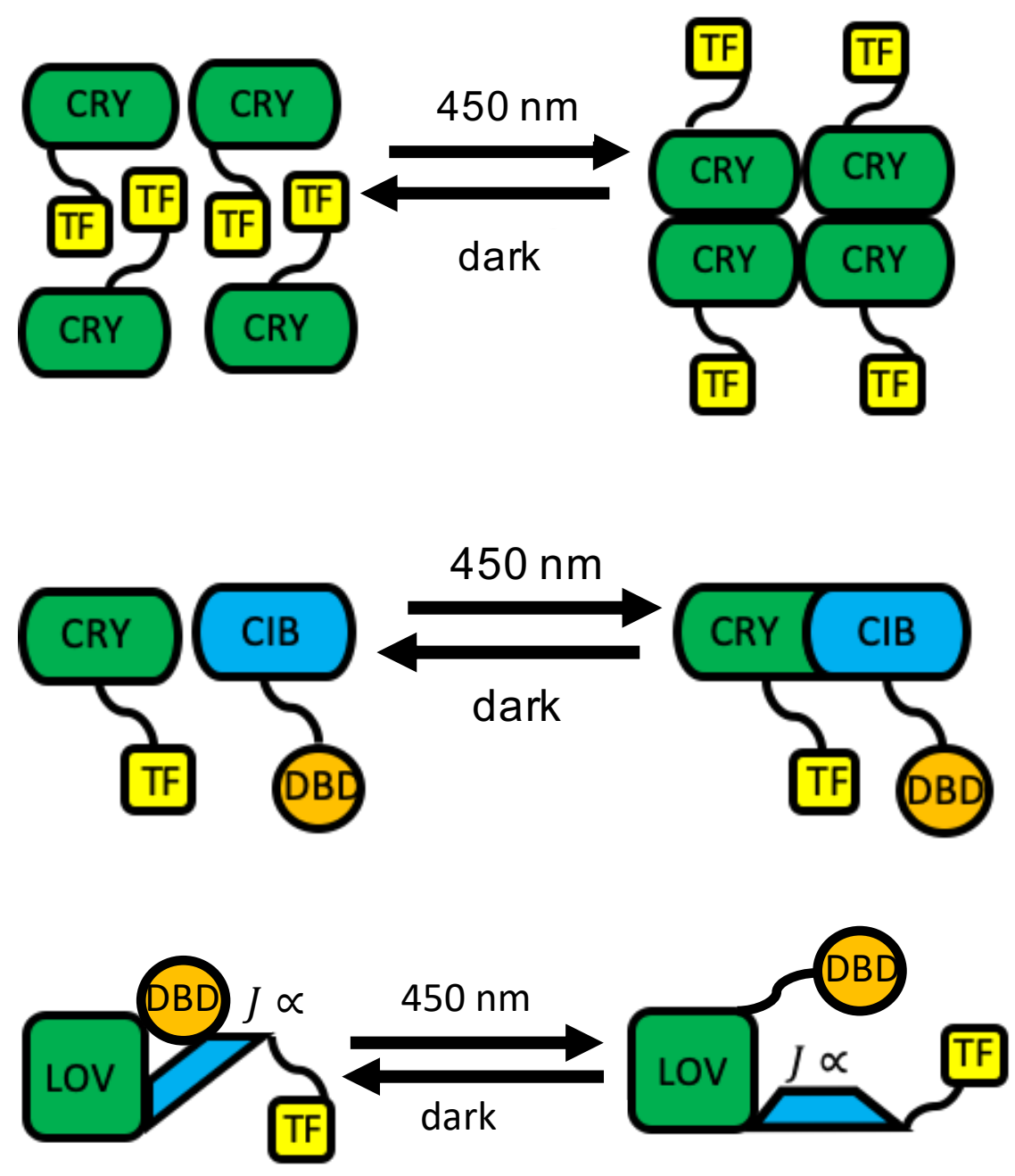

Tissue penetration depth of light

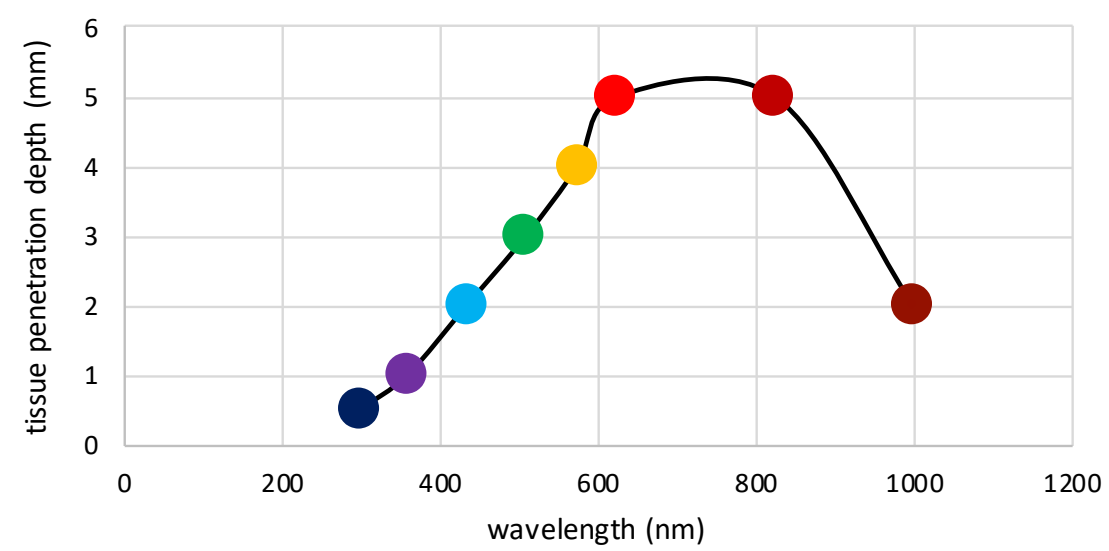

